\title{
PUR-PIR foam produced based on poly(hydroxybutyl citrate) foamed founded with different factories
}

\author{
Joanna Liszkowska*, Bogusław Czupryński, Joanna Paciorek-Sadowska, Marcin Borowicz \\ Kazimierz Wielki University, Bydgoszcz, Poland \\ "Corresponding authors: e-mail: liszk@ukw.edu.pl
}

\begin{abstract}
A poly(hydroxybutyl citrate) $\mathrm{p}(\mathrm{HBC})$ was obtained. The product compound produced in the solution during esterification, was added to rigid polyurethane-polyisocyanurate foams (PUR-PIR). The amount of petrochemical polyol in the foams was decreased in favor of the $\mathrm{p}(\mathrm{HBC})$ from 0.1 to 0.5 equivalent. The foams were foamed in two ways: with distilled water (W foams) and with Solkane 365/227 (S foams). The examination results of both foam series were compared. They showed that the foams foamed with water have higher softening temperature than the foams foamed with solkane. The retention values for both foam series are around $91-95 \%$, and water absorption in the range of $0.7-3.2 \%$. The anisotropy coefficient did not exceed 1.08 (the lowest value being 1.01).
\end{abstract}

Keywords: rigid foam, polyurethane, polyol, citric acid, condensation.

\section{INTRODUCTION}

Polyurethanes (PURs) are one of the most biocompatible biomaterials whose properties can be tailored to a large extent. PURs consist of alternately oriented hard and soft segments. The hard segments are derived from diisocyanate and chainmextender, while the soft segments are composed of linear, long-chain diols. Due to the segmented structure of PURs, it is possible to tailor their properties ${ }^{1,2}$. Properties of polyurethane products obtained depend on the type of raw materials used (particularly polyol), and additives used in synthesis. Ionescu and others ${ }^{3}$ synthesized polyols from castor oil for rigid polyurethanes. Mixture of castor oil, crude glycerol and untreated lignin applied Carrico and others ${ }^{4}$. Polyol from sunflower oil was synthesised by Omrani and others ${ }^{5}$. Rigid polyurethane foams were synthesized with two types of polyglycerol (using 35 and $70 \mathrm{wt} . \%$ ) with different molecular weights and hydroxyl numbers by Piszczyk and others ${ }^{6}$. They received new "green" polyurethane-polyglycerol foams. The hydroxylalkyl derivatives of silicic and boric acid were synthesized by Lubczak ${ }^{7}$. In the reaction with oxiranes or alkyl carbons, oligoetherols are produced which can be used for obtaining rigid foams (oligoetherols from silicic acid) and elastic foams (oligoetherols from boric acid). However the rigidness of the latter can be increased by adding the product of the hydroxylalkylation of melamine with propylene carbonate. The foams produced based on the mentioned compounds are characterized by high thermal resistance and compressive strength. Kania and Lubczak $^{8}$ used barbituric acid and glycidol to produce oligoetherols with higher thermal resistance. The production of polyols based on vegetable oils is an interesting solution. Both rigid $^{9}$ and elastic ${ }^{10,11}$ foams can be obtained based on them. They are a cheaper alternative to petrochemical polyestrols and polyetherols. They are used in the furniture and cosmetic industries. Biodegradable polyols used for bio-foam synthesis were synthesized by Wojturska and others ${ }^{12}$. The industry demands for polyols to be modified in such a way to produce nonflammable materials out of them. As a result of which, melamine, melamine polyphosphate, melamine isocyanurate ${ }^{13,14}$ and the derivatives of boric acid and urea ${ }^{15-20}$ or hydroxides and their mixtures ${ }^{21,22}$ are used as antipyrenes. They significantly improve flame resistance of the materials without deteriorating their mechanical parameters. The cost of the polyurethane material is determined by the cost of raw materials used for its production. New and cheap production materials are sought after to make polyurethanes economically competitive. One of those materials is citric acid, which is used during the synthesis of new polyols for polyurethane-polyisocyanurate foams $(\text { PUR-PIR })^{23-25}$. Instead of polyol modification, powder fillers, such as mineral volcanic tuff ${ }^{26}$, rapeseed press cake $^{27,28}$, waste product of bituminous coal burning ${ }^{29}$, wooden fibers ${ }^{30}$, are used to improve the properties of polyurethanes. Those modifiers especially decrease the flammability and brittleness of rigid foams and other materials.

The aim of the research is the synthesis of new, cheap filler for foams. The obtained compound has to have the ability to lower the production cost of rigid foams without any deterioration of their properties in comparison to the reference foams.

(W0 and S0) obtained based on the petrochemical polyether (Polios 250PA). Foams were synthesized by utilizing a foaming agent available on the market Solkane (S foams). As an alternative, other foams were foamed using water ( $\mathrm{W}$ foams). The properties of foams synthesized with water or solkane based on CHB citrate were compared to the properties of reference foams produced based on the petrochemical Polios. The obtained foams can be used as cheap protection for appliances during shipment or as packaging. The packaging should be the lowest cost of a given product, negligible enough to become a part of the product's price. It should be light and durable. The foams synthesized by us meet those demands. Their density does not exceed $60 \mathrm{~kg} /$ $\mathrm{m}^{3}$ and their compressive strength (according to growth direction) is above $0.2 \mathrm{MPa}$ - which meets the PUR packaging standards. 


\section{EXPERIMENTAL}

\section{Characteristics of raw materials}

The Polios 250PA polyether (polyoxypropylenehexol with $420 \mathrm{mgKOH} / \mathrm{g}$ hydroxyl number, molecular weight of 660) produced by Zakłady Chemiczne PCC Rokita S.A. in Brzeg Dolny (Table 1), and a technical polymeric diisocyanate Ongronat CR 30-20 produced in Hülls (Hungary), whose main component is diphenylmethane 4.4'-diisocyanate, were used to prepare rigid PUR-PIR foams. The density of Ongronat at $25^{\circ} \mathrm{C}$ was $1.23 \mathrm{~g} /$ $\mathrm{cm}^{3}$, viscosity was $200 \mathrm{mPa} \cdot \mathrm{s}$ and the content of NCO groups was $31.0 \%$. The polyether and diisocyanate were characterized according to ASTM D 2849-69 and ASTM D 1638-70 standards. The catalyst used to produce the foams was anhydrous potassium acetate (POCh Gliwice) applied in a form of $33 \%$ solution in diethylene glycol - DEG (catalyst 12), and "DABCO 33LV" (triethylenediamine, Hülls, Germany) applied in a form of $33 \%$ solution in DEG. The foam structure stabilizer was polyoxosilanepolyoxyalkene surfactant „Silicone Tegostab 8460" (Witco, Sweden). Carbon dioxide formed during a reaction of water with isocyanate groups acted as blowing agent. Another blowing agent used in synthesis was HFC Solkane 365/227 (manufacturer Arcema, France). A liquid flame retardant Roflam P (TCPP, tri(2-chloro-1-methylethyl) phosphate), Albright and Wilson, Great Britain, was added to the foams. Foam synthesis was conducted by adding HBC (Kazimierz Wielki University, Technical Instytute, Bydgoszcz). For obtaining p(HBC) the monohydrate N 1560 2-hydroxypropane-1.2.3-tricarboxylic acid produced by Brenntag Poland LLC company in Kędzierzyn Koźle was used. The amount of water in the acid was $7.5 \%-8.8 \%$. The acid was dried in ventilated drier until the water volume reached $3.35 \%$. The water amount was measured in a moisture analyzer according to the PN-A-79005-04/1997 Polish Standard. The butane-1.4-diol (POCh, Gliwice, Poland) and sulphur acid as catalyst was used in the synthesis (POCh, Gliwice, Poland). $\mathbf{p}(\mathbf{H B C})$ compound was added to the foams in the amount of $0 \mathrm{wt} . \%$ to $15 \mathrm{wt} . \%$.

\section{Synthesis of $p(\mathrm{HBC})$}

An esterification reaction was carried out using butane-1,4-diol (1,4-BD, $135 \mathrm{~g})$ and citric acid (CA, $96 \mathrm{~g}$ ), using concentrated $(96 \%) \mathrm{H}_{2} \mathrm{SO}_{4}$ (us a catalyst, $0.24 \mathrm{~g}$ ). Hydroxybutyl citrate $\mathrm{p}(\mathrm{CHB})$ was obtained - scheme 1 .

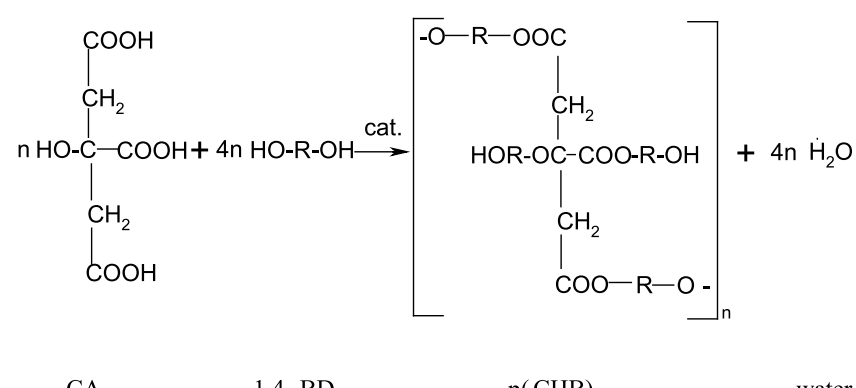

CA 1.4- BD

$\mathrm{p}(\mathrm{CHB})$ water

in which $\mathrm{R}=\mathrm{CH}_{2}-\mathrm{CH}_{2}-\mathrm{CH}_{2^{-}} \mathrm{CH}_{2}$

in which $\mathrm{R}=\mathrm{CH}_{2}-\mathrm{CH}_{2}-\mathrm{CH}_{2}-\mathrm{CH}_{2}$

Synthesis was conducted in three-neck glass flask (500 $\mathrm{cm}^{3}$ vol. each) equipped with reflux condenser, thermometer, stirrer and Deana-Stark's head. The reaction took place under xylene. The generated water was collected in the head. Flask contained BD which was mixed with CA. $\mathrm{H}_{2} \mathrm{SO}_{4}$ was added at the end of synthesis. Flask was heated for about 20 minutes in an electric bath (until the acid dissolved, i.e. about $85^{\circ} \mathrm{C}$ ). It was heated until the substances inside them boiled. From this moment the reaction time was measured. Synthesis 1 took 4 hours altogether. The temperature of the reaction was between $105^{\circ} \mathrm{C}-129^{\circ} \mathrm{C}$. The reaction was conducted in 3 temperature stages (Table 2). Since the product was a gelatinous with high viscosity, the $\mathrm{CHB}$ was heated to $70^{\circ} \mathrm{C}$ before it was added to the foams. The $\mathrm{CHB}$ was treated as a non-reactive filler because the viscosity, density and hydroxyl number needed for calculating the foam recipe could not be examined.

\section{Characterization techniques of $\mathrm{p}(\mathrm{CHB})$}

The synthesized product CHB was cooled and analyzed. FTIR analysis was performer to identify the characteristic groups in foams. Nicolet iS10 FTIR spectrophotometer by Thermo Scientific was used for the examination of FTIR, which had a specter range from 7800 to $350 \mathrm{~cm}^{-1}$ and maximum resolution capability $<0.4 \mathrm{~cm}^{-1}$ with DTGS detector. Viscosity was determined using a Hoeppler viscosimeter according to the standard PN-86/C-98082.04. In the studies used a ball no. 5: diameter $-14.002 \mathrm{~mm}$, weight $-11.071 \mathrm{~g}$, the density -7.7019 , has the ball: for the upper limit of 6.790 , for the lower limit 6.789. The molar mass was determined by cryoscopic method using the Beckmann thermometer according to the industry standard BN-640530-02. ${ }^{1} \mathrm{H}-\mathrm{NMR}$ spectra were recorded at $500 \mathrm{MHz}$ on a Bruker UltraShield spirometer (Rhe-

Table 1. Recipes PUR-PIR foam foamed with water (W foams) and Solkane (S foams)

\begin{tabular}{|c|c|c|c|c|c|c|c|c|c|}
\hline Compound & Unit & WO & W5 & W10 & W15 & So & S5 & $\mathrm{S} 10$ & $\mathrm{~S} 15$ \\
\hline $\mathrm{HBC}$ & $\begin{array}{c}\text { \% wt. } \\
\text { [g] }\end{array}$ & $\begin{array}{l}0 \\
0\end{array}$ & $\begin{array}{c}5 \\
12.0 \\
\end{array}$ & $\begin{array}{l}10 \\
24.0\end{array}$ & $\begin{array}{l}15 \\
36.0\end{array}$ & $\begin{array}{l}0 \\
0\end{array}$ & $\begin{array}{c}5 \\
12.0\end{array}$ & $\begin{array}{l}10 \\
24.0\end{array}$ & $\begin{array}{l}15 \\
36.0\end{array}$ \\
\hline Water & $\begin{array}{c}\mathrm{R} \\
{[\mathrm{g}]}\end{array}$ & $\begin{array}{l}0.7 \\
2.43 \\
\end{array}$ & $\begin{array}{l}0.7 \\
2.43\end{array}$ & $\begin{array}{l}0.7 \\
2.43 \\
\end{array}$ & $\begin{array}{l}0.7 \\
2.43\end{array}$ & - & - & - & - \\
\hline Solcane $365 / 227$ & $\begin{array}{c}\mathrm{R} \\
{[\mathrm{g}]}\end{array}$ & - & - & - & - & $\begin{array}{r}0.7 \\
21.2 \\
\end{array}$ & $\begin{array}{r}0.7 \\
21.2 \\
\end{array}$ & $\begin{array}{r}0.7 \\
21.2 \\
\end{array}$ & $\begin{array}{r}0.7 \\
21.2 \\
\end{array}$ \\
\hline
\end{tabular}

Table 2. The course of HBC synthesis process

\begin{tabular}{|c|c|c|c|c|c|}
\hline Product & Reaction step & $\begin{array}{c}\text { Temp. of synthesis, } \\
{\left[{ }^{\circ} \mathrm{C}\right]}\end{array}$ & $\begin{array}{c}\text { Time of synthesis, } \\
{[\mathrm{h}]}\end{array}$ & $\begin{array}{c}\text { Amount of distilled } \\
\text { water, }\left[\mathrm{cm}^{3}\right]\end{array}$ & Product characteristics \\
\hline $\mathrm{HBC}$ & $\begin{array}{c}\text { I } \\
\text { II } \\
\text { III }\end{array}$ & $\begin{array}{l}125-129 \\
116-118 \\
105-106\end{array}$ & - & $\begin{array}{c}- \\
- \\
50.0\end{array}$ & $\begin{array}{c}- \\
- \\
\text { liquid highly viscous, jellied }\end{array}$ \\
\hline
\end{tabular}


instetten, Germany) using of DMSO-d6 as the solvent and heksamethylenedisiloksane as the internal pattern.

\section{Synthesis of polyurethane foams}

Foam recipes (Table 1) were designed based on the literary sources $[31,32]$. Detailed calculations are provided in the articles [33, 34].

The foams were prepared in a laboratory scale by one-stage method from the two-component system at the equivalent relation of $-\mathrm{NCO}$ to $\mathrm{OH}$ groups equal to 3:1 (accordance with the provisions to rigid foams). The component A was obtained by the precise mixing (1800 rpm, $10 \mathrm{~s}$ ) of the suitable amounts of Polios 250PA (76.3 $\mathrm{g})$, catalyst $12(2.4 \mathrm{~g})$, catalyst DABCO $(6.1 \mathrm{~g})$, antypirene Roflam P (47.6 g), surface-active agent Silicone Tegostab 8460 (4.7 g), porophors: distilled water (3.4 g) or Solkane (21.2 g). p(HBC) was added in amount of from $12 \mathrm{~g}$ to $36 \mathrm{~g}$ (for both the $\mathrm{W}$-series and the S-series foam) - Table 1. Component B was polymeric diisocyanate Ongromat 30-20 added in amount of 167.1 g. The amount of isocyanate was chosen based on the ratio of isocyanate groups to hydroxyl groups, which for the rigid polyurethane-polyisocyanate foams was 3:1. The calculated amount of isocyanate was expanded by the mass of isocyanate necessary for the reaction with water. As a result of the reaction, a gas which foams the reactive mixture is produced $-\mathrm{CO}_{2}$. The isocyanate group chemical equivalent (eq.) was calculated according to the following equation 2 :

eq. $=\frac{4200}{\% \mathrm{NCO}}$

where: \% NCO stands for the content of $\mathrm{NCO}$ group in polyisocyanate.

\section{Processing parameters of foams}

The course of the process temperature inside the foam measured using laboratory thermometer inserted into the center of each of foam. The parameters of processing (start time, growth time and gelation time) were measured during synthesis using a stopwatch. The start time was the time measured from mixing all the components until the so-called "state of cream". This is shown by starting to increase the volume of the foam. The rise time was the time measured by a stopwatch from mixing all components of the foam until the maximum volume of the foam. The gel time was the time measured by a stopwatch from mixing all foam components, until the free surface of the foam stops sticking to a clean glass rod. After expanding, the foam was removed from the tray and thermostated during $4 \mathrm{~h}$ at the temperature of $120^{\circ} \mathrm{C}$. Then, they were seasoned for $48 \mathrm{~h}$ at the temperature of $20 \pm 4^{\circ} \mathrm{C}$ and cut to samples of respective dimensions.

The maximum temperature produced inside the foam was measured using thermocouple placed inside the foam, in its central part.

\section{Thermal properties}

Thermal properties of foams as well as changes in linear, volume and mass dimensions were determined according to ISO 1923:1981 and PN-ISO 4590:1994.

Heat properties of the foams are determined by examining their softening temperature. The Vicat apparatus is used for temperature measurement. The softening temperature, as the thermal resistance to compression, was marked using cube samples with $20 \mathrm{~mm}$ edge, according to the foam rising direction, in compliance with DIN 53424 standard. Foam samples were subjected to compressive load of $24.52 \mathrm{kPa}$ at $50^{\circ} \mathrm{C}$ temperature for an hour. The softening temperature is the temperature at which the sample was compressed by $2 \mathrm{~mm}$.

\section{Apparent density}

The apparent density of the examined foams was determined as the ratio between foam mass to its geometrical volume, using cube samples with $50 \mathrm{~mm}$ edge, in compliance with ISO 845-1988 standard.

\section{Identification of characteristic groups - see Characteri- zation techniques of $\mathrm{p}(\mathrm{CHB})$}

\section{Structure}

Eclipse microscope 400 POL (Canon, Japan), was used to take photos of the foam structure (transmitting light, magnification -4 times).

The foam structure was determined using Hitachi TM 3000 scanning electron microscope (SEM) with EDS attachment. The samples were dusted with a layer of gold that was about $6 \mathrm{~nm}$ thick. Based on the height and the width of cell cross-sections, it was possible to estimate the anisotropy coefficient (AC) of the foams according to the equation 3 :

$\mathrm{AC}=\frac{\text { cell height }}{\text { cell width }}$

\section{Compressive strength}

Was measured using strength machine Tira Test 2200 (ISO 844:1993: DIN 53420). Brittleness was measured according ASTM C-421-61. Water absorption and absorbability were tested according to DIN 53433 standard. The marking method was the measurement of hydrostatic buoyancy of a sample with $150 \times 150 \times 25(\mathrm{~mm})$ dimensions submerged in distilled water for 24 hours.

\section{Water absorption and absorbability}

Water absorption (A) calculated according to equation 4 , and absorbability (I), according to equation 5:

$\mathrm{A}=\frac{\mathrm{m}_{2}-\mathrm{m}_{0}}{\mathrm{~m}_{0}} \cdot 100 \%$

$\mathrm{I}=\frac{\mathrm{m}_{1}-\mathrm{m}_{0}}{\mathrm{~m}_{0}} \cdot 100 \%$

where: $\mathrm{m}_{0}$ - the mass of the sample before examination, $\mathrm{g}$, $\mathrm{m}_{1}$ - the mass of the sample after $24 \mathrm{~h}$ of submerging, $\mathrm{g}$, $\mathrm{m}_{2}$ - the mass of the sample after drying, $\mathrm{g}$,

\section{Flammable properties}

The behavior of the obtained foams in flame was determined with the following tests:

\section{Butler test}

Simplified flammability test chimney test (vertical Butler) according to ASTM D3014-73. Apparatus used for the flammability test of the vertical test consists of a vertical column with dimensions 300 × 57 × $54(\mathrm{~mm})$ which three walls are made of sheet metal, and the fourth 
is a movable window. The assay was performed on six samples with dimensions of 150 × 19 × 19 mm. Before combustion of the sample was weighed to an accuracy of $0.0001 \mathrm{~mm}$, and then placed inside the chimney. Founded window and the sample was applied the flame of the burner fueled by propane - butane at the time of $10 \mathrm{~s}$. Then the torch moved away and stopwatch measured the time free samples of smoking and retention (residue after burning) in the vertical test. The retention was calculated according to the equation (6):

$\mathrm{R}=\frac{\mathrm{m}}{\mathrm{m}_{0}} \cdot 100 \%$

where:

$\mathrm{R}$ - retention, \%,

$\mathrm{m}_{0}-$ mass of the sample before burning, $\mathrm{g}$,

$\mathrm{m}-$ mass of the sample after ignition, $\mathrm{g}$.

\section{Horizontal test}

The burning estimations using the horizontal method were done according to the PN-78 C-05012 standard. The method marks the speed of surface flame spreading on a sample with $150 \times 50 \times 13(\mathrm{~mm})$ dimensions, placed horizontally and exposed to a flame at one end (propane-butane burner). The speed of surface flame spreading is a speed at which the head of the flame moved on the surface of the examined sample of flammable material. During the examination the sample foam is placed on a net fixed horizontally and a burner is placed at one side of the foam's end for $60 \mathrm{~s}$. A line is drawn across the $125 \mathrm{~mm}$ mark from the side where the burner is placed. The distance which the head of the flame covers and the time for the head to reach the marked line need to be noted. If the foam extinguishes before the flame reaches the marker, then the foam is categorized as self-extinguishing. If the foam keeps burning, an average burning time of the marked distance can be determined or the speed of flame spreading (in $\mathrm{mm} / \mathrm{s}$ ) based on the distance the head of the flame covers in a specific time.

\section{RESULTS AND DISCUSSION}

\section{Receiving and properties of citrate $p(\mathrm{CHB})$}

Was noticed, that the amount of distilled water is greater than the expected amount calculated based on the reaction's stoichiometry. This can be a sign of additional esterification reaction of the obtained hydroxyalkyl citrates with the non-reacted carboxyl groups of the neighboring particles. Also, ethers can be created between the hydroxyl group of citric acid and the used glycol. The structure of the obtained products in one particle contain multiple structural fragments of citric acid and O-R-O bridges connecting citric acid's particles (according to the scheme 1). The obtained structure and the presence of O-R-O groups were confirmed by the IR (Fig. 1) and ${ }^{1} \mathrm{HNMR}$ (Fig. 2) spectra. The spectrum was interpreted using public tables. In the IR spectrum, there is a wave with small intensity at $965 \mathrm{~cm}^{-1}$ coming from $\mathrm{OH}$ group present in the carboxyl group. Moreover, the spectrum contains $\mathrm{C}-\mathrm{O}$ bonds with high intensity in the ester at $1220 \mathrm{~cm}^{-1}$, a wave at $1073 \mathrm{~cm}^{-1}$ coming from I-order hydroxyl group, and at $1036 \mathrm{~cm}^{-1}$ related to $\mathrm{C}-\mathrm{O}-\mathrm{C}$ ester bonds. There also is a valence vibration wave of $\mathrm{OH}$ groups at $3446 \mathrm{~cm}^{-1}$. The wave at 1724 $\mathrm{cm}^{-1}$ is a $\mathrm{C}=\mathrm{O}$ wave (characteristic for aliphatic esters) and the wave at $2954 \mathrm{~cm}^{-1}$ is related to the stretching vibrations of the methylene group.

There is a clear signal with 12.3 ppm chemical shift in the ${ }^{1} \mathrm{H}-\mathrm{NMR}$ spectrum which indicates the presence of non-reacted carboxyl group. The hydroxyl groups are represented by a signal at $5.6 \mathrm{ppm}$ which fades after the addition of $\mathrm{D}_{2} \mathrm{O}$. The methylene groups in the structure of the citric acid and the obtained esters are represented by signals at $2.45 \mathrm{ppm}$ and $2.70 \mathrm{ppm}$. The signals coming from protons of methylene groups that occur in $\mathrm{O}-\mathrm{CH}_{2}-\mathrm{CH}_{2}-\mathrm{O}$ bridges which were obtained as a result of polymer condensation, are present at the 4.2 ppm chemical shift. However, the signal of a methylene group linked directly with the hydroxyl group has a 3.6 ppm chemical shift. Examined the viscosity of $\mathrm{p}(\mathrm{CHB})$ is $41287.3 \mathrm{mPa} \cdot \mathrm{s}$.

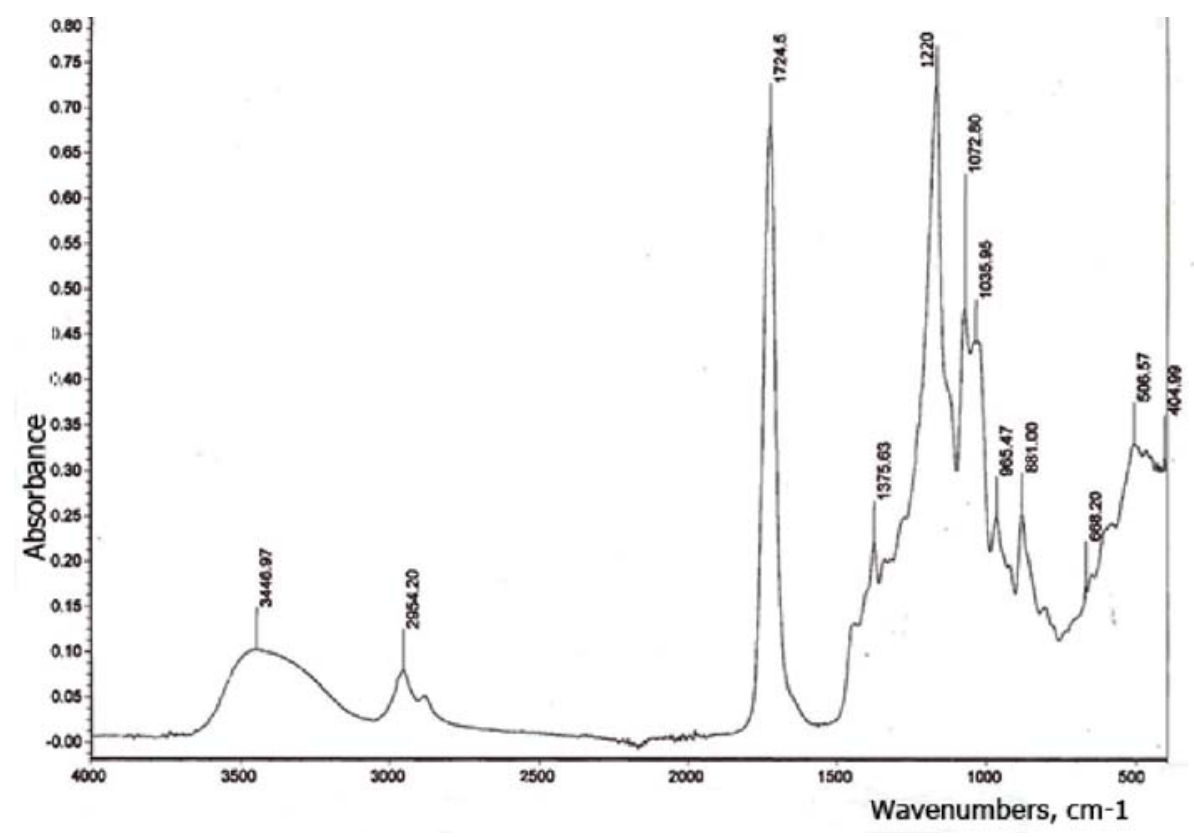

Figure 1. IR spectrum $\mathrm{CHB}$ 


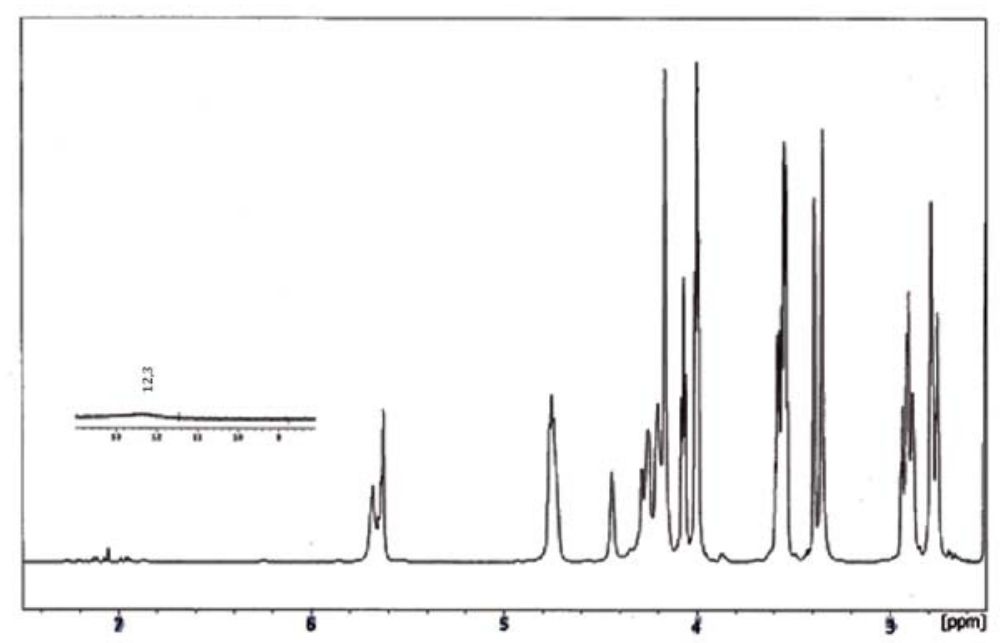

Figure 2. ${ }^{1} \mathrm{H}-\mathrm{NMR}$ spectrum $\mathrm{CHB}$

\section{Properties of foams}

\section{Processing parameters and $T_{\max }$ temperature}

Moreover, the start time for W5-W15 and S5-S15 foams containing $\mathrm{p}(\mathrm{CHB})$ compound was shortened a bit in comparison to the W0 and S0 reference foams start times, by 1 and 3 seconds respectively. However, the growth and gelation times increased linearly along with the increasing amount of CHB (Table 3). Foams foamed with water had longer growth and gelation parameters in comparison to foams foamed with solkane. During the foaming process, maximum temperature $T_{\max }$ was measured for each foam. For the foams foamed with water, the $T_{\max }$ decreases gradually from $145^{\circ} \mathrm{C}$ (W0 foam) to $135^{\circ} \mathrm{C}$ (W10 foam), but after adding $0.3 \mathrm{R}$ of $\mathrm{CHB}$ it rises again to $155^{\circ} \mathrm{C}$ (W15 foam). The situation is reversed for foams foamed with solkane, the $\mathrm{T}_{\max }$ increases from $120^{\circ} \mathrm{C}$ (S0 foam) to $146^{\circ} \mathrm{C}$ (S5 foam) and then decreases to $121^{\circ} \mathrm{C}$ (S15 foam).

Table 3. Processing parameters of foams and maximum reaction temperature $\left(\mathrm{T}_{\max }\right)$ in foams during foaming

\begin{tabular}{|l|c|c|c|c|}
\hline Foam & $\begin{array}{c}\text { Start time, } \\
{[\mathrm{s}]}\end{array}$ & $\begin{array}{c}\text { Growth time, } \\
{[\mathrm{s}]}\end{array}$ & $\begin{array}{c}\text { Gelation } \\
\text { time, }[\mathrm{s}]\end{array}$ & $\begin{array}{c}\mathrm{T}_{\max }, \\
{\left[{ }^{\circ} \mathrm{C}\right]}\end{array}$ \\
\hline W0 & 10 & 42 & 20 & 145 \\
\hline W5 & 9 & 54 & 22 & 141 \\
\hline W10 & 9 & 57 & 25 & 135 \\
\hline W15 & 9 & 57 & 32 & 155 \\
\hline S0 & 7 & 30 & 15 & 120 \\
\hline S5 & 7 & 34 & 19 & 146 \\
\hline S10 & 7 & 35 & 23 & 130 \\
\hline S15 & 7 & 40 & 26 & 121 \\
\hline
\end{tabular}

\section{Apparent density}

The apparent density of all the foams is around 49-59 $\mathrm{kg} / \mathrm{m}^{3}$ (Table 4). Foams foamed with water showed slightly larger mass loss $\Delta \mathrm{m}$ (up to $9.2 \%$ ) in comparison to foams foamed with solkane (7.7\%). Reversed situation was observed for the change in volume $(\Delta \mathrm{V})$. The volume of foams foamed with water increased (up to $2.2 \%$ ) after 48 hours of thermostating, and for foams foamed with solkane it slightly decreased (up to $-3.3 \%$ ).

\section{Structure of foams}

The pictures of foams' structure (Figs. 3-6) show that the foams should have good durability. In a serie of W foams (foaming of water) is slightly greater amount of inclusions in the form of cells having a larger diameter (Fig. 3) compared with the structure $\mathrm{S}$ foams (foaming solcane, Fig. 5). The cell shape of foams sliced opposite and according to the growth direction is similar, i.e. spherical. It can be stated that anisotropy should be around 1. Due to this, compressive strength in both directions should not be much different. The cells are small, usually equal in size, at least when adding $5 \%$ mass of $\mathrm{p}(\mathrm{CHB})$. In W10 and W15 foams there are visible individual larger cells (Fig. 3). This may indicate a too low amount of the surface-active agent in those foams. Foams containing PIR bond require specific silicone derivatives which improve compound mixing and help stabilize the structure before cross-linking. Too low amount of silicone with a $1.5 \%$ amount of $\mathrm{p}(\mathrm{CHB})$ compound is the probable cause of the lowering of foams' compressive strength. Based on the photos from the microscope, it can be assumed that a reaction between isocyanate (Ongronat) and $\mathrm{p}(\mathrm{CHB})$ compound took place, the same as between Ongronat and Polios, as the pictures do not show individual cells, comparing to the situation when the powder filler (non-active) was added [35]. The cells of the foam foamed with water without the $\mathrm{p}(\mathrm{CHB})$ compound are slightly more elongated towards the growth direction (Fig. 4a). It is a sign of a lowered compressive strength of the foam tested according to the growth direction.

Table 4. Results of thermal resistance and apparent density of the foams

\begin{tabular}{|l|c|c|c|c|}
\hline Foam & Change of volume $\Delta \mathrm{V},[\%]$ & Change of mass $\Delta \mathrm{m},[\%]$ & Apparent density, $\left[\mathrm{kg} / \mathrm{m}^{3}\right]$ & Softening point, $\left[{ }^{\circ} \mathrm{C}\right]$ \\
\hline W0 & 2.2 & -7.3 & 48.9 & 106 \\
\hline W5 & 1.8 & -7.1 & 50.2 & 129 \\
\hline W10 & 2.1 & -9.2 & 51.7 & 173 \\
\hline W15 & 1.9 & -8.6 & 51.1 & 1 \\
\hline S0 & -3.1 & -4.5 & 56.7 & 110 \\
\hline S5 & -3.3 & -4.2 & 49.2 & 127 \\
\hline S10 & -0.9 & -3.9 & 49.8 & 108 \\
\hline S15 & -1.8 & -7.7 & 58.7 & 110 \\
\hline
\end{tabular}



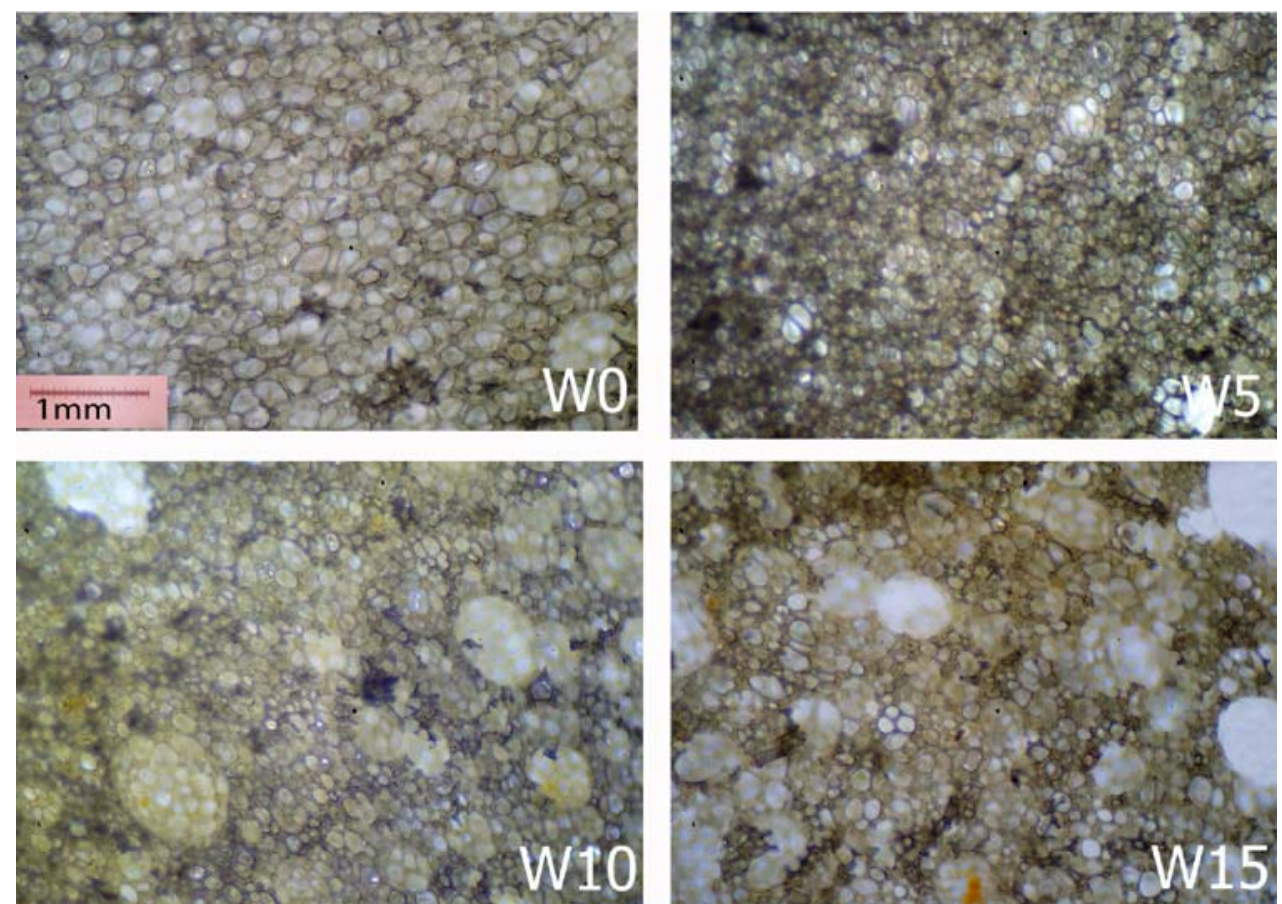

Figure 3. Photos of foam structure for $\mathrm{W}$ series (foamed with water) taken opposite to the growth direction
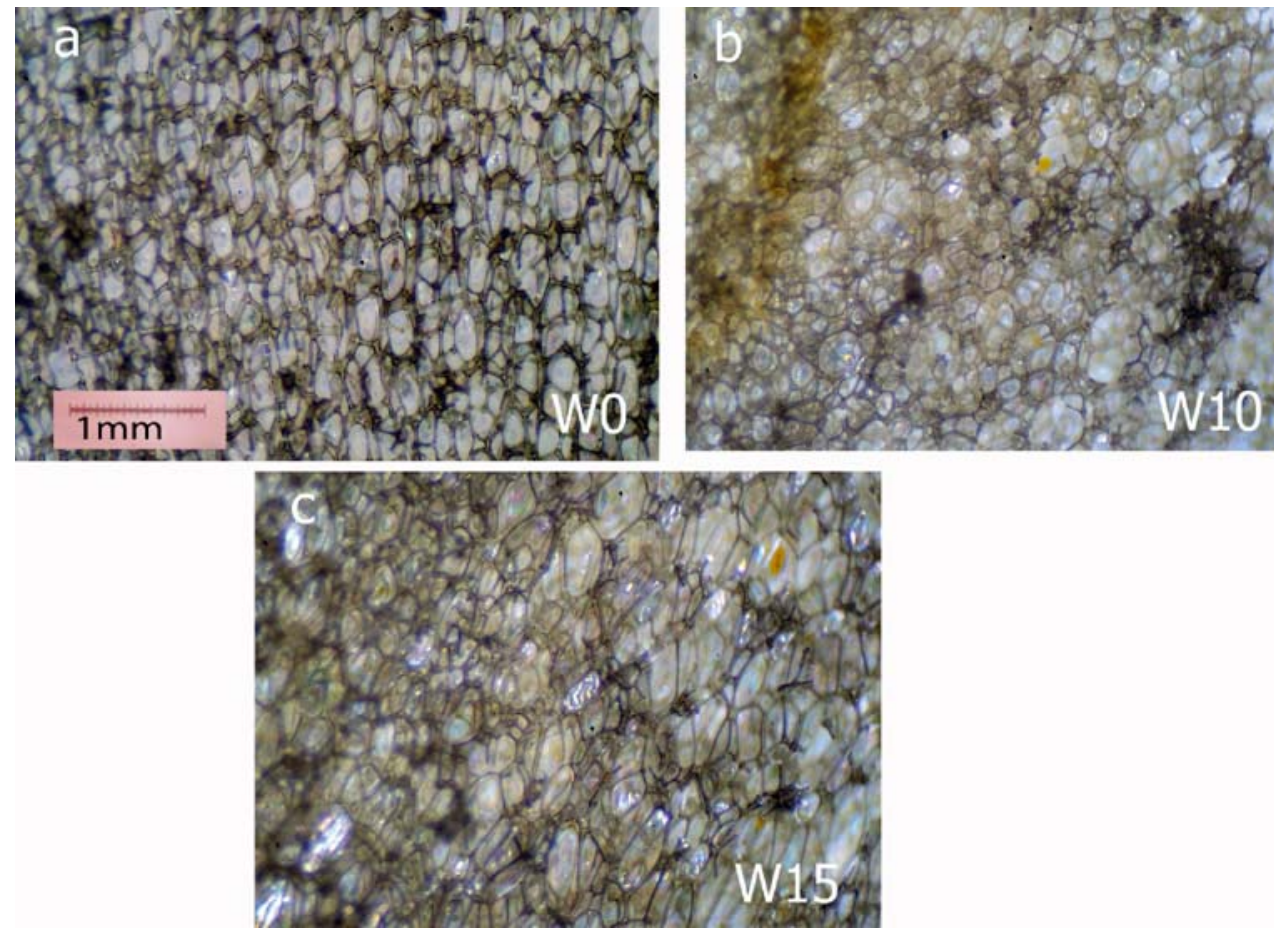

Figure 4. Photos of foam structure for $\mathrm{W}$ series (foamed with water) taken according to the growth direction

However, with the addition of $10 \%$ mas. of $\mathrm{p}(\mathrm{CHB})$ compound, the cells became spherical again (Fig. 4b), and the addition of $15 \%$ mas. of $\mathrm{p}(\mathrm{CHB})$ causes another elongation according to the growth direction (Fig. 4c).

\section{SEM and anisotropy coefficient}

The anisotropy coefficient (CA) was calculated based on the width and height of the cells examined with SEM (Fig. 7). The measured anisotropy (Table 5) shows that

Table 5. Results of physico-mechanical examination of the foams

\begin{tabular}{|l|c|c|c|c|c|c|c|}
\hline Foam & Brittleness, [\%] & Retention, [\%] & $\begin{array}{c}\text { Burning speed, } \\
{[\mathrm{mm} / \mathrm{s}]}\end{array}$ & $\begin{array}{c}\text { Water } \\
\text { absorption, } \\
{[\text { vol\%] }}\end{array}$ & $\begin{array}{c}\text { Absorbability, } \\
{[\text { vol\%] }}\end{array}$ & $\begin{array}{c}\text { AC } \\
\text { Oxygen index, } \\
\text { [\%] }\end{array}$ \\
\hline W0 & 2.9 & 95.3 & 1.03 & 2.7 & 30.5 & 1.08 & 25.7 \\
\hline W5 & 0.65 & 93.9 & 0.92 & 2.8 & 39.0 & 1.01 & 25.5 \\
\hline W10 & 0.67 & 91.7 & 0.83 & 3.2 & 40.8 & 1.01 & 25.6 \\
\hline W15 & 3.03 & 94.4 & 0.79 & 2.3 & 33.8 & 1.03 & 25.5 \\
\hline S0 & 7.60 & 94.9 & 1.00 & 0.7 & 23.3 & 1.05 & 25.7 \\
\hline S5 & 0.00 & 94.4 & 0.97 & 1.6 & 29.9 & 1.02 & 25.6 \\
\hline S10 & 0.56 & 93.7 & 0.87 & 1.9 & 33.3 & 1.01 & 25.8 \\
\hline S15 & 0.95 & 94.4 & 0.83 & 1.2 & 55.8 & 1.03 & 25.6 \\
\hline
\end{tabular}



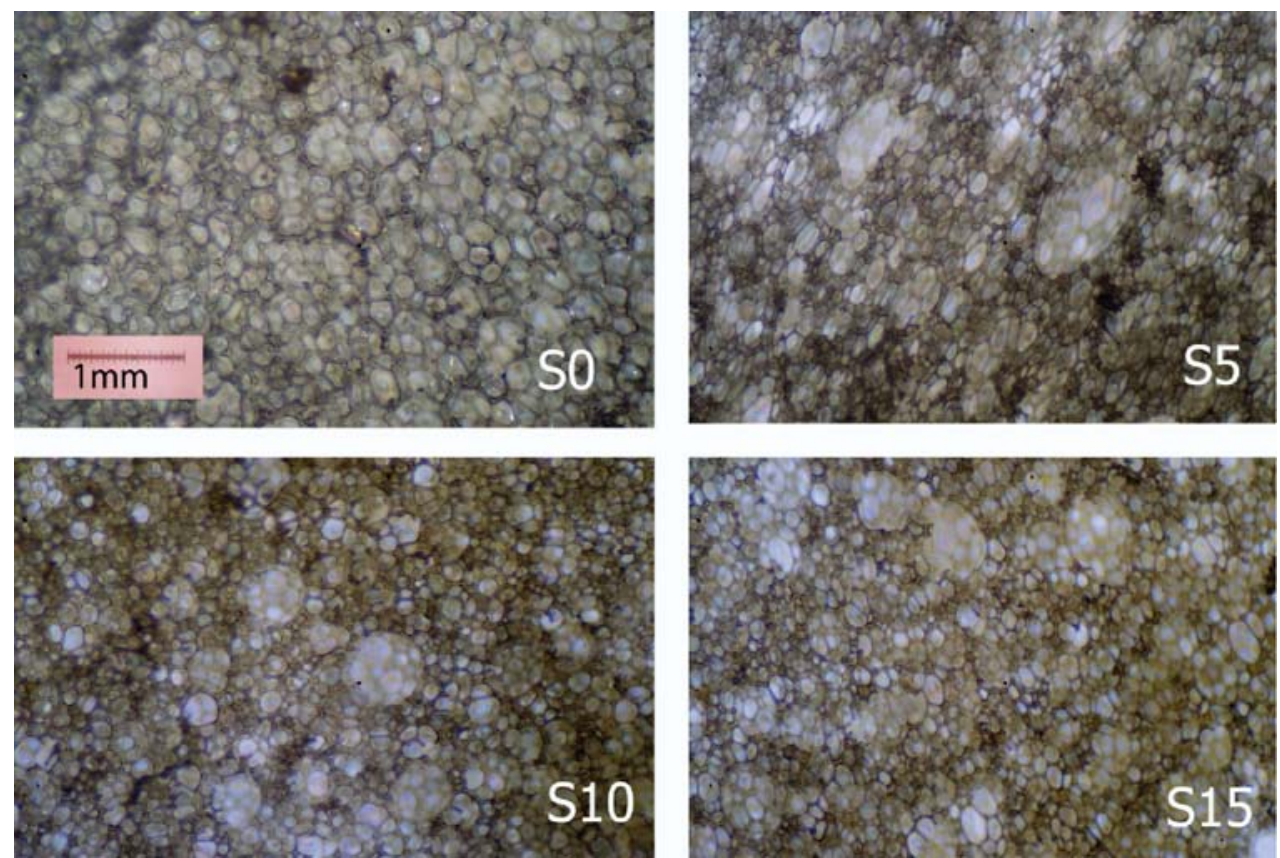

Figure 5. Photos of foam structure for S series (foamed with Solkane) taken opposite to the growth direction
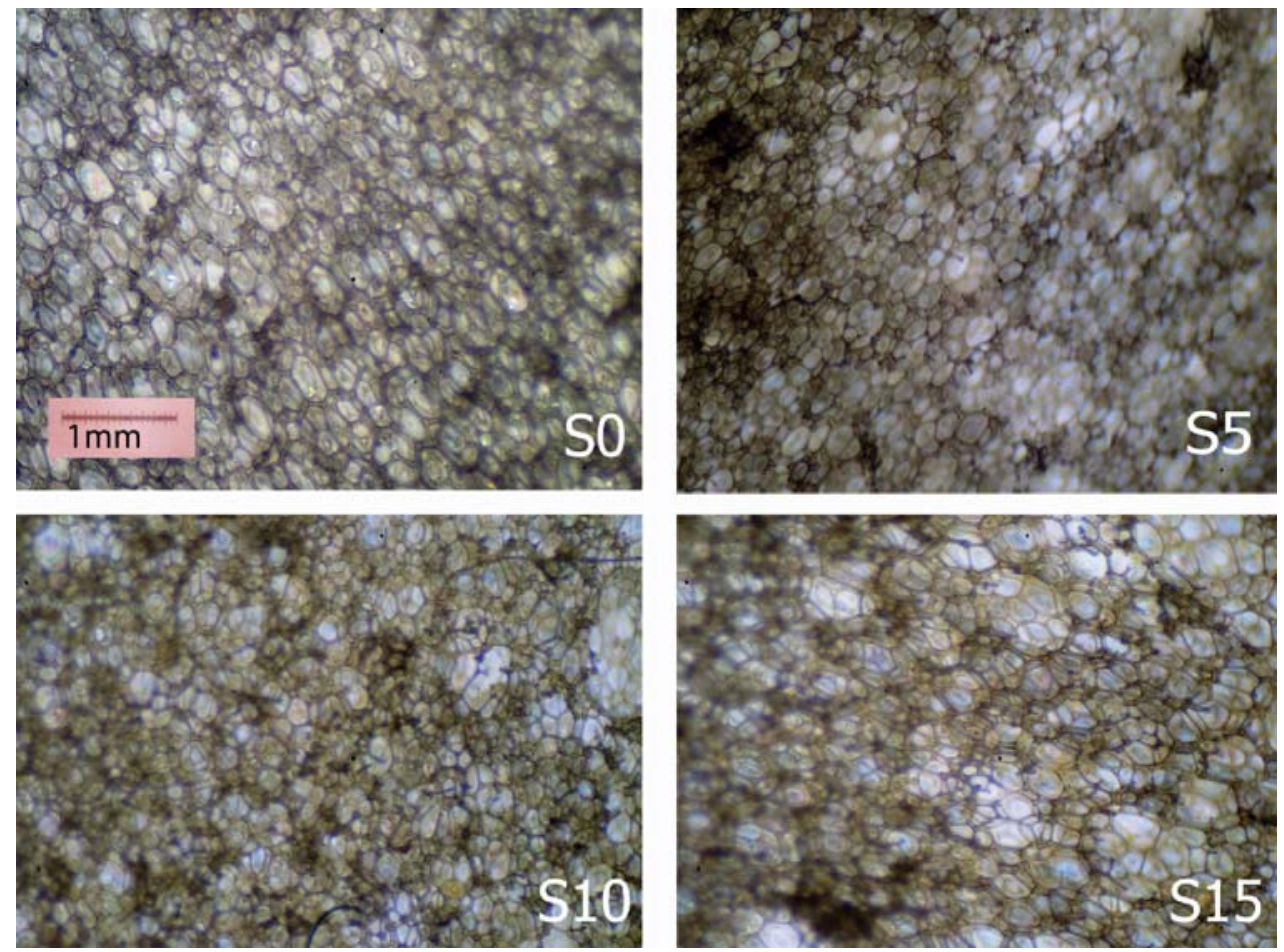

Figure 6. Photos of foam structure for S series (foamed with Solkane) taken according to the growth direction

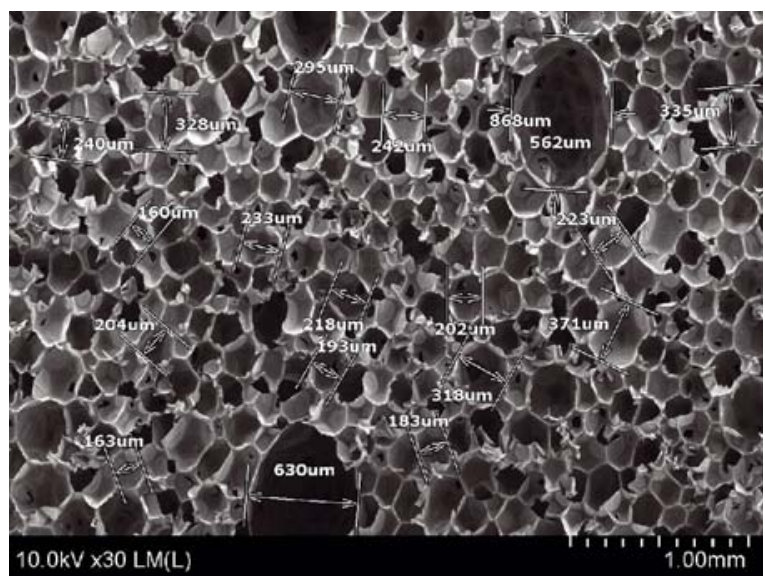

Figure 7. Sample SEM picture of PUR-PIR foam the most spherical shape belongs to the foams containing $5 \mathrm{wt} \%$ and $10 \mathrm{wt} \%$ of the $\mathrm{p}(\mathrm{CHB})$ compound, foamed both with water and solkane, as their anisotropy coefficient (CA) is closest to 1 . The most elongated cells belong to the foams not containing $\mathrm{CHB}$, i.e. the $\mathrm{CA}$ for W0 and S0 was 1.08 and 1.05 respectively.

\section{Compressive strength}

The examination of compressive strength performed opposite to the growth direction for $\mathrm{S}$ and $\mathrm{W}$ foams was in the range from $292 \mathrm{kPa}$ to $390 \mathrm{kPa}$ (Fig. 8a). The examination opposite the growth direction showed values between $140 \mathrm{kPa}$ and $230 \mathrm{kPa}$ (Fig. 8b). 
(a)

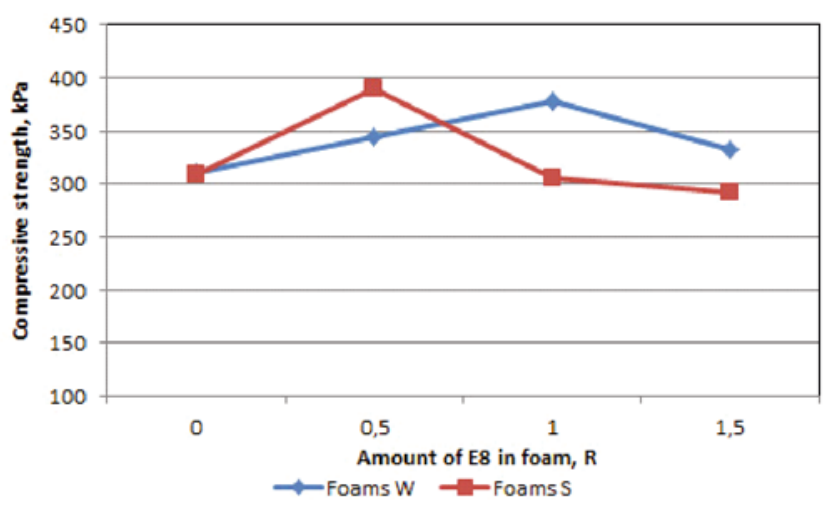

(b)

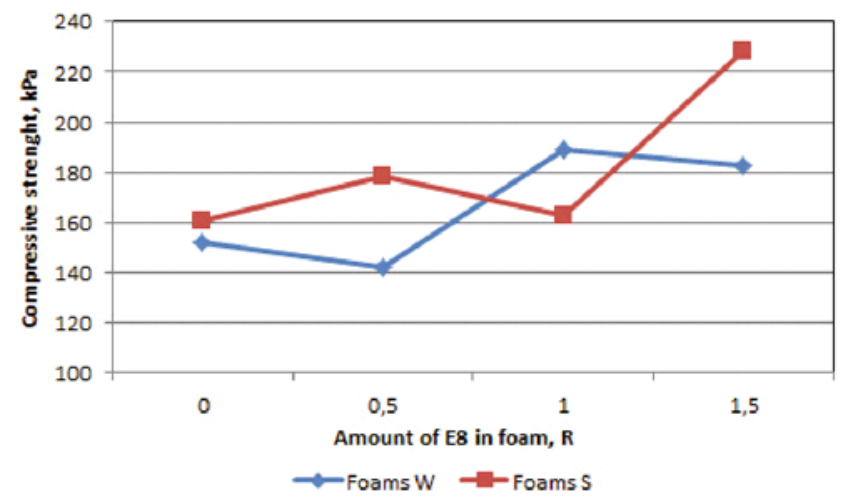

Figure 8. Compressive strength of PUR-PIR foams examined opposite to the growth direction (a) and according to the growth direction (b)

\section{FTIR of foams}

FTIR analysis of foams (Fig. 9) showed presence of isocyanurate ring $\left(1700 \mathrm{~cm}^{-1}-1500 \mathrm{~cm}^{-1}\right)$ and urethane bond $\left(1700 \mathrm{~cm}^{-1}\right)$ in foams. Moreover, hydroxyl group -OH was observed within the range from 3100 to 3300 $\mathrm{cm}^{-1}$. The FTIR analysis confirmed that the obtained foams are polyurethane-polyisocyanurate (PUR-PIR).

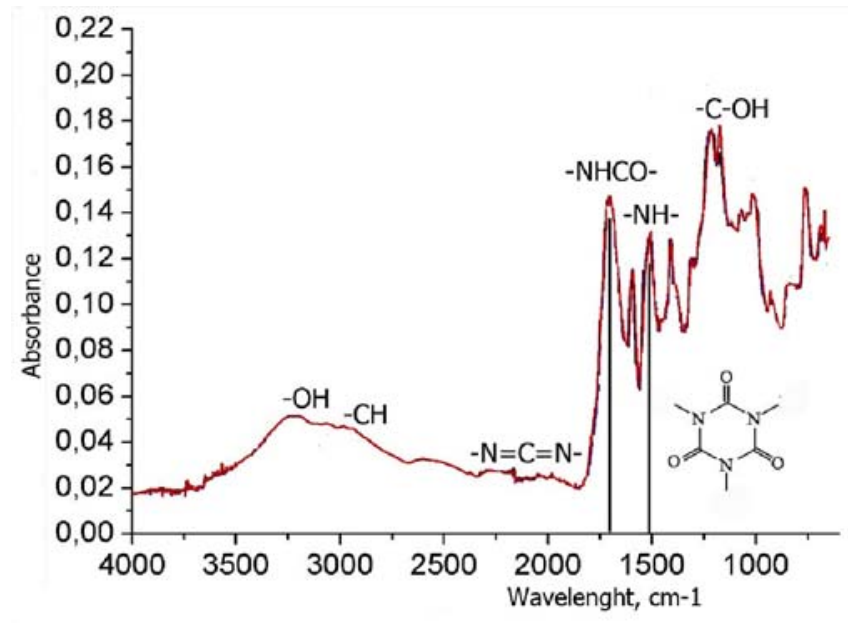

Figure 9. FTIR of PUR-PIR foam

\section{Water absorption}

Water absorption for foams foamed with water is two times higher than for foams foamed with solkane and ranges from $2.3 \%$ to $3.2 \%$ (W foam) and from $0.7 \%$ to $1.9 \%$ ( $\mathrm{S}$ foam). This is due to the structure of foams in which the cells showing inclusions of large diameter (W foam, Fig. 3) than in foams serie S (Fig. 5). Linear dependency was not observed between water absorption and the amount of $\mathrm{p}(\mathrm{CHB})$ compound in the foams. Absorbability of foams foamed with water is in the range of $30.5 \%-40.8 \%$. For foams foamed with solkane, there is a visible influence of the amount of $\mathrm{p}(\mathrm{CHB})$ compound on the foam absorbability, which increases along with the amount of CHB concentration, from $23.3 \%$ (S0 foam) to $55.8 \%$ (S15 foam).

\section{Softening point}

The softening point $\left(\mathrm{S}_{\mathrm{p}}\right)$ of foams foamed with water increases from (W0) to $186^{\circ} \mathrm{C}(\mathrm{W} 15)$ - Table 4 . For foams foamed with Solkane, there was no linear dependency between $\mathrm{S}_{\mathrm{p}}$ and the amount of $\mathrm{p}(\mathrm{CHB})$ in the foam. The retention (residue after burning) of all foams exceeds $91 \%$ and reaches around $95 \%$. All foams are characterized by very low brittleness in the range from $0 \%$ to $7.6 \%$ (Table 5). Oxygen index was about $25 \%$ and the amount of citrate or not the type of the foaming agent had no effect on its value.

\section{CONCLUSIONS}

Obtained two series of foams ( $\mathrm{W}$ and $\mathrm{S}$ ) foamed by water or solcane. Foams contain compound of condensation of citric acid (CA) with butane-1.4-diol (1.4-BD) named $\mathrm{p}(\mathrm{CHB})$ - hydroxybutyl citrate. Construction of $\mathrm{p}(\mathrm{CHB})$ was confirmed by IR and ${ }^{1} \mathrm{NMR}$. The structure are included, among others, O-R-O bridges and C-O-C bonds. Two foams also foamed as two reference foam, not containing $\mathrm{p}(\mathrm{CHB})$ ( $\mathrm{W} 0$ and $\mathrm{S} 0$ ). The highest temperature of reaction $\left(\mathrm{T}_{\max }\right)$ during the synthesis of foam was observed for the water-blown foams but with the addition of $\mathrm{p}(\mathrm{CHB})\left(155^{\circ} \mathrm{C}\right.$ for $\mathrm{W} 15$ foam $)$. Foaming using solcane reduce the maximum temperature of the reaction foams $121^{\circ} \mathrm{C}$ (S15 foam). With similar density of the foams $\left(49-59 \mathrm{~kg} / \mathrm{m}^{3}\right)$ it was possible to compare other properties of the foams. The best properties were attributed to the foams with the addition of $5 \mathrm{wt} \%$, $10 \mathrm{wt} \%$ and $10 \mathrm{wt} \%$ of the $\mathrm{p}(\mathrm{CHB})$ compound, which was reflected in their structure. The shape of the cells, which was examined in both directions (according and opposite to the growth direction), was spherical. It is also confirmed by the foams' anisotropy, which is nearly 1 . Foams foamed with water (W foams serie) showed higher values of their softening point in comparison to foams foamed with solkane ( $\mathrm{S}$ foams serie). The compressive strength for both foam series are similar and range between $290 \mathrm{kPa}$ and $390 \mathrm{kPa}$. Water absorption for foams foamed with water is two times higher than for foams foamed with solkane and ranges from $2.3 \%$ to $3.2 \%$ (W foam) and from $0.7 \%$ to $1.9 \%$ ( $\mathrm{S}$ foam). Such a water absorption is due to the foam structure in the $\mathrm{W}$ foams as compared to $\mathrm{S}$ foams.

\section{LITERATURE CITED}

1. Kucińska-Lipka. J., Sienkiewicz, M., Gubanska, I. \& Zalewski, S. (2017). Microwave radiation in the synthesis of urethane prepolymers. Eur. Polym. J. 88, 126-135. 
2. Cornille, A., Auvergne, R., Figovsky, O., Boutevin, B. \& Caillol, S. (2017). A perspective approach to sustainable routes for non-isocyanate polyurethanes. Eur. Polym. J. 87, 535-552.

3. Ionescu, M., Radojc 'ic', D., Wana, X., Shrestha, M.L. \& Petrovic', Z.S. (2016). Upshaw Highly functional polyols from castor oil for rigid polyurethanes. Eur. Polym. J. 84, 736-749.

4. Carriço, C.S., Fraga, T. \& Pasa, V.M.D. (2016). Production and characterization of polyurethane foams from a simple mixture of castor oil, crude glycerol and untreated lignin as bio-based polyols. Eur. Polym. J. 85, 53-61.

5. Omrani, I., Farhadian, A., Babanejad, N., Shendi, H.K., Ahmadi, A. \& Nabid, M.R. (2016). Synthesis of novel high primary hydroxyl functionality polyol from sunflower oil using thiolyne reaction and their application in polyurethane coating. Eur. Polym. J. 82, 220-231.

6. Piszczyk, Ł., Strankowski, M., Danowska, M., Hejna, A. \& Haponiuk, J.T. (2014). Rigid polyurethane foams from a polyglycerol-based polyol. Eur. Polym. J. 57, 143-150.

7. Lubczak, J., Chmiel, E., Barcikowska, M. \& Bułdak, N. (2015). New oligoetherols and polyurethane foams prepared using silicic acid derivatives of boric acid. Materials Conference - Modification of Polymers. Status and prospects in 2015. Scientific Papers of the Institute of Technology of Organic and Polymers, Wroclaw University of Technology, Kudowa Zdrój.

8. Kania, E. \& Lubczak, J. (2014). A new method for the synthesis of the oligoeterols with pyrimidine ring using barbituric acid and glycidol. Polymers (in Polish) 59, 851-854.

9. Radwańska, J., Kurańska, M., Szczepkowski, L. \& Prociak, A. (2015). The study bio-rigid polyurethane foams for use in the cosmetic industry. Materials Conference - Modification of Polymers. Status and prospects in 2015. Scientific Papers of the Institute of Technology of Organic and Polymers, Wroclaw University of Technology, Kudowa Zdrój.

10. Prociak, A. \& Malewska, E. (2015). Effect of the isocyanate index on the properties of flexible polyurethane bio-foams (in Polish). Materials Conference - Modification of Polymers. Status and prospects in 2015. Scientific Papers of the Institute of Technology of Organic and Polymers, Wroclaw University of Technology, Kudowa Zdrój.

11. Prociak, A. \& Malewska, E. (2015). The effect of nanosilica filler on the foaming process and properties of flexible polyurethane foams obtained with rapeseed oil-based polyol. Polymers, 60, 472-479.

12. Wojturska, J., Frącz, W., Stagraczyński, R. \& Grendysa, P. (2015). Synthesis and evaluation of selected properties of polyurethanes obtained using biopoliols. Materials Conference - Modification of Polymers. Status and prospects in 2015 Scientific Papers of the Institute of Technology of Organic and Polymers, Wroclaw University of Technology, Kudowa Zdrój.

13. Lubczak, J. \& Lubczak, R. (2015). Melamine and its salts as an additive flame retardants to polyurethane heat-resistant foams. Materials Conference - Modification of Polymers. Status and prospects in 2015. Scientific Papers of the Institute of Technology of Organic and Polymers, Wroclaw University of Technology, Kudowa Zdrój.

14. Czech-Polak, J., Przybyszewski, B., Heneczkowski, M., Czulak, A. \& Gude, M. (2016). Effect of environmentally-friendly flame retardants on fire resistance and mechanical properties of rigid polyurethane foams. Polymers, 61, 113-116.

15. Paciorek-Sadowska, J., Czupryński, B., Liszkowska, J. \& Kotarska, K. (2012). Fire-safe polyurethane plastic modified new flame retardant - use of new methods for flammability test. Enginee. Chem. Equip. 51, 58-60.

16. Paciorek-Sadowska, J., Czupryński, B. \& Liszkowska, J. (2014). Preparation of new compound reducing flammability. European Chemistry Congress - 5th EuCheMS, Istambul, Turky (2014).

17. Paciorek-Sadowska, J., Czupryński, B. \& Liszkowska, J. (2015). Boron-containing fire retardant rigid polyurethane- polyisocyanurate foams. Part I-polyol precursors based on boric acid and di(hydroxymetyl)urea derivatives. J. Fire Sci. 33, 37-47.

18. Paciorek-Sadowska, J., Czupryński, B., Liszkowska, J. (2015). Boron-containing fire retardant rigid polyurethanepolyisocyanurate foams. Part II-preparation and evaluation. J. Fire Sci. 33, 38-68.

19. Paciorek-Sadowska, J., Czupryński, B., Liszkowska, J. (2012). Fire-safe polyurethanes modified with new antipyrene. Chemist, 66, 297-306.

20. Paciorek-Sadowska, J. (2010). Modification of PURPIR foams by boroorganic compound obtained on the basis of bis(hydroxymethyl)urea. Polymers, 55 (2010) pp. 373-378.

21. Song, H., Jianqiang, L.J., Xue, F. \& Cheng, F. (2016). Flame retardant properties of gas sealing materials used in coal mines. Polymers 61 (2016), 266-271.

22. Eliwa, R., Oleksy, M., Heneczkowski, M., Oliwa, R., Budzik, G., Kozik, B., Markowska, O., Strachota, A. (2015). Fire-resistant hybrid epoxy composites. Polymers 60, 667-670.

23. Liszkowska, J., Czupryński, B., Paciorek-Sadowska, J. (2015). Tris(hydroxydietylene)-2-hydroxypropane-1,2,3trikarboksylate for rigid PUR-PIR foams. J. Polymer Enginee. 35, 743-751.

24. Liszkowska, J., Czupryński, B. \& Paciorek-Sadowska, J. (2015). Synthesis of rigid PUR-PIR foams with a new polyol. Enginee. Equip. Chem. 54, 10-11.

25. Liszkowska, J., Czupryński, B., Paciorek-Sadowska, J. \& Moraczewski, K. (2015). The effect of UV radiation on the properties of rigid PUR-PIR foams. Adv. Polym. Technol. 2015, 0, 21631-21639. DOI 10.1002/adv.21631 (on-line: ADV-10-14-220).

26. Paciorek-Sadowska, J., Czupryński, B., Borowicz, M. \& Liszkowska, J. (2016). Use of tuff for the production of rigid polyurethane-polyisocyanurate foams. Chem. Ind. 95, 42-47.

27. Paciorek-Sadowska, J., Czupryński, B., Borowicz, M. \& Liszkowska, J. (2015). Research on obtaining new type of polyurethane composite - rapeseed press cake. Part 1. The strength tests and flammability of a new composite. Chemnitz Technomer 12-13 November 2015.

28. Paciorek-Sadowska, J., Czupryński, B., Borowicz, M. \& Liszkowska, J. (2015). New plastic polyurethane involving bio-filler. Polimers 60, 586-591.

29. Paciorek-Sadowska, J., Czupryński, B., Borowicz, M. \& Liszkowska, J. (2014). The use of a by-product of burning coal in the production of polyurethane plastics. Enginee. Equip. Chem. 53, 99-100.

30. Kurańska, M., Prociak, A., Cabulis, U. \& Kirpluks, M. (2015). Water-blown polyurethane-polyisocyanurate foams based on bio-polyols with wood fibers. Polymers 60 (2015) 705-712.

31. Czupryński, B., (2004). Issues of polyurethane chemistry and technology. Akademia Bydgoska, Bydgoszcz.

32. Wirpsza, Z. (1991) Poliuretanes. Chemistry, technology, application. WNT, Warsaw.

33. Liszkowska, J., Czupryński, B. \& Paciorek-Sadowska, J. (2016). Thermal properties of polyurethane-polyisocyanurate (PUR-PIR) foams modified with tris(5-hydroxypentyl)-2-hydroxypropane-1,2,3-tricarboxylate. J. Adv. Chem. Enginee. 6(2), $148-154$.

34. Czupryński, B., Liszkowska, J. \& Paciorek-Sadowska, J. (2008). Modification of rigid polyurethane-polyisocyanurate foam selected powder fillers. Polymers 53(2008) 48-52.

35. Czupryński, B., Liszkowska, J. \& Paciorek-Sadowska, J. (2013). The influence silica, kaolin and epoxy resin on heat and thermal properties of rigid PUR-PIR foams. J. Cell. Plast. 49, 375-390. 